\title{
College Nannies \& Tutors: Franchise Business Models
}

\author{
Mark Spriggs (University of St. Thomas)
}

\begin{abstract}
KEYWORDS: Retail Trade, Entrepreneurship, Startups, student entrepreneurs, Student innovators.
\end{abstract}

Joe Keeley, founder of College Nannies and Tutors (CNT), hung up the phone. Another insurance company had declined to underwrite the coverage he needed for CNT to expand; he had contacted over forty companies with no success. But Keeley still believed in the business opportunity, and based on the awards he had received, so did others. He received the Pentair Prize for Entrepreneurial Achievement from his alma mater, the University of St. Thomas, and won several local and regional contests culminating in being named the Global Collegiate Entrepreneur of the Year.

After an article in the Minneapolis/St. Paul Business Journal describing how CNT had started as a class project and was now a fledgling business, a local businessman invested in CNT, and the two of them were now working to expand the business. Keeley had opened three locations, and two people had recently contacted him saying they were interested in opening up their own CNT locations. He knew it was time to grow the business, and believed franchising was the right business model for CNT, but if the to-be-franchisees couldn't get affordable insurance for worker's compensation and general liability coverage of the nannies and tutors, he would have to consider other methods for how franchisees did placements of the nannies and tutors.

\section{The Genesis of the Concept}

During college, Keeley worked in the summer as a nanny (he preferred the term "manny") for two young boys and their sister. Keeley soon realized that he was much more than a babysitter; he was an active role model for the children. When parents asked if he knew other college students interested in being a nanny/manny, he saw the need for a unique and specialized service that connected parents with safe and reliable childcare providers. His initial concept was College Summer Nannies, and he recruited other college students who were looking for part-time work and wanted to make a positive difference by working with school-age children.
College Summer Nannies was successful enough that Keeley decided to build a business around recruiting and placing nannies with families. The first challenge he faced was overcoming the common practice of families hiring and paying a nanny directly, usually in cash and for low wages. Despite a number of high-profile politicians and others being caught employing a nanny without paying the required payroll taxes, many families continued to pay in cash, and attempted to avoid the legal requirements of having an employee. They did not want the hassle and expense of doing all the paperwork required to employ someone in their household, and they assumed (or hoped) they wouldn't be caught. Keeley knew that if CNT wanted to attract families, he had to have a strong value proposition - strong enough to justify the cost of having CNT handle the administrative work of finding and screening a nanny, and to justify the higher wages required when paying the various payroll taxes that were not getting paid in a cash system. So the value proposition of CNT was formed around the idea that they took over the hassle and risk of finding, screening and doing the payroll process for the families wanting to hire a nanny.

Early in CNT's history, Keeley added tutoring services to his nanny business. First, tutoring had complementary seasonality since the demand for nannies was highest in the summer, and the tutoring business was strong during the rest of the year. And both businesses focused on CNT's core strength of working with children. But the two businesses had differences too. The nanny market is a large, highly fragmented market, and the margins are relatively low. By contrast, the tutoring business is a lower-volume business, has more and larger competitors, but offers much higher margins. Together, the combination would allow CNT to assist families from cradle to college, and CNT could build a strong lifetime value from each CNT client family.

\section{Market Size and Opportunity}

In 2006, the Department of Health and Human Services 
estimated the nanny or non-parental childcare market at $\$ 10$ billion. In-home nannies were replacing daycare providers for affluent and middle-income families looking to reduce hourly or part-time childcare. Nannies were also being used more often in one-parent and nontraditional households. Parents with newborns were concerned about the level of personalized attention that their child receives in a traditional day care center, and turned to nannies to give their child more personal care. In-home nannies could also accommodate the needs of older children who have other activities in the summer and after school, or are too old to fit a traditional afterschool or summer program.

According to the Wall Street Journal, tutoring was a $\$ 4$ billion market with a few well-known companies (e.g, Sylvan Learning) and many other local and regional operators. As some school systems struggle to meet the needs of a growing number of students with diverse learning needs, parents are seeking better opportunities for their children outside the classroom. One solution was to engage a tutor, which can be a more inexpensive alternative to a private school environment, especially for the middle class. Also, with the passage of the No Child Left Behind Act, schools, caregivers and more parents, at all economic levels, now have access to funds for private tutors.

\section{Building a Sustainable Business Model}

Keeley believed a franchise business model was the best strategy to grow the company and protect the CNT brand, but in a traditional franchise, the nannies and tutors would be employees of the franchisee, and need worker's compensation and general liability insurance coverage. The problem was finding an insurance carrier to cover the nannies and tutors when they went into a client's home to work with children. Most insurance underwriters weren't interested in providing the coverage, primarily because there wasn't a claims history available for covering in-home nannies and tutors, and especially for an independent, geographically dispersed network like CNT envisioned. The few quotes Keeley did get were very high. If CNT had to pay too high of rates (assuming they could get coverage at all), the business Keeley envisioned may not viable and Keeley would have to consider a different business model for his CNT franchisees that would still make the CNT concept attractive to potential CNT franchisees.

\section{Franchising Model}

Keeley had taken a class at St. Thomas on franchising, and he initially believed franchising was the right business model for CNT. In a franchise system, the owner/creator of the franchise (franchisor) offers independent business people (franchisees) the opportunity to own a unit(s) of the franchise and to use the franchise's methods and brand name, plus they receive training and other assistance from the franchisor. Most franchises charge an initial one-time franchise fee which covers training and support from the franchisor to get the unit open. Franchise fees vary greatly and reflect the value of the franchise's brand, and the level of support a franchisee receives prior to opening. For those that charge a fee, they generally start around $\$ 5000$ and may exceed $\$ 50,000$ for large, well known systems. Franchisees also pay an ongoing royalty to the franchisor, usually a percentage of sales or a flat monthly rate. Rates vary but many are in the range of $4 \%-8 \%$ of gross sales. In exchange, the franchisor agrees to provide ongoing support, training, advertising programs and other services to help the franchisee be successful. In some cases, the franchisor may charge other fees like a marketing fee to fund system wide advertising, or the franchisor may sell products to the franchisee such as food commodities, services/supplies, or merchandise for resale as described in the franchise agreement.[i]

\section{Advantages}

Franchising offers several advantages for the franchisor compared to operating their own corporate system. First, franchisees are responsible for building their own unit(s) and providing the operating capital, so the franchisor doesn't have to raise the capital required to build and run the retail outlets. Since franchisees have an ownership stake in the business, and earn a return based on how well they manage their unit's costs and revenues, the franchisor gets motivated owner/franchisees who have an incentive to work hard and be successful.

\section{Drawbacks}

The franchising model does have drawbacks, however. When the franchisor uses franchisees, the franchisor loses some control of the business. While the franchise agreement specifies the rules and processes the franchisee must follow, the franchisee may believe there is a better way to do something and/or not be willing to put in the effort to maximize the return for the franchisor. 
Those different ideas about how something should be done can cause conflict in the relationship between the franchisor and franchisee. Another potential problem is even if the franchise contract stipulates the terms and responsibilities of both parties, monitoring and compliance enforcement can be expensive and difficult for the franchisor. Furthermore, it is not possible to write a franchise contract that anticipates every situation and contingency, so gray areas may still exist in the rights and responsibilities of both parties. Finally, if market conditions change, and the franchisor wants to revise the contract, the franchisee may refuse to change the terms of the current contract, which may run 10 years or more.

One of the decisions for CNT is how to get revenue from their franchisees in the form of a royalty or other fee. The most common method is some percentage of revenue. In most franchises, a royalty as a percentage of sales ( $6 \%-8 \%$ is common) is paid to the franchisor. This gives the franchisor an incentive to help franchisees grow their sales because that growth earns the franchisor a greater return on their investment. And as long as the sales growth is still profitable, the franchisee earns more as well. However, some franchisees eventually see the royalty payments as a drain on their profits, especially since many feel as time goes on, they need less support from the franchisor but the royalty rate does not decrease.

Another less common method is for the franchisor to charge franchisees a flat royalty rate; a few existing franchises charge as low as $\$ 250$ / month, with others charge as much as $\$ 1500$. The key is the franchisor has to charge enough to cover the costs of the franchisee support system which includes ongoing training, support systems (e.g., scheduling software and marketing assistance), and processes for monitoring franchisee's for conformance to the system's standards.

The choice of the royalty rate structure has implications for the entire system. If a franchise system uses a flat rate royalty, the system has to have a larger number of units in order to earn the franchisor an adequate return on their franchisee support and monitoring investments, which can lead to over-saturation of units. Some franchisees like the flat rate system because as their business grows, their royalty payment to the franchisor does not increase, allowing them to keep more of their units' revenue.
For franchisees, buying a franchise can be less risky than opening an independent business. With a franchise, the franchisee gets an established brand name, a proven business/operations plan, and ongoing assistance from the franchisor, all of which greatly increase the likelihood the franchisee will succeed. From a franchisor's perspective, the best franchisee is one that is committed to operating the franchised unit by following the rules and processes spelled out in the contract and operations manual. Of course, that means certain individuals may not be a good candidate to be a franchisee because they are unwilling to abide by the rules set out in the franchise agreement. The key is for the franchisor and franchisee to understand the interdependent nature of their relationship and be committed to fulfilling their contractual requirements and obligations in a manner that benefits both parties.

Keeley knew he wanted to use the franchise model, but the specifics of the franchisees' business model, and so Keeley's relationship with the franchisees, depended on how, or perhaps who, would provide the necessary liability insurance for the nannies \& tutors.

\section{Independent Contractor Model}

A different business model that would allow CNT franchisees to avoid carrying liability/risk insurance is to classify the nannies and tutors as independent contractors rather than employees. According to IRS rules, the three primary factors for determining if someone is an independent contractor are:[ii]

Behavioral Control - the worker is considered an employee if $\mathrm{s} /$ he receives extensive instructions on how to perform the work or training about required procedures and methods.

Financial Control - the worker is an independent contractor if $\mathrm{s} /$ he has significant investment in the work, has unreimbursed business expenses, and/or has an opportunity for profit or loss.

Relationship of the Parties - the worker is an employee if $\mathrm{s} / \mathrm{he}$ receives benefits such as health insurance or paid leave, or when other factors are unclear, but there is a written contract specifying what the worker and business intend.

If CNT's nannies and tutors are classified as independent contractors, and not employees of CNT franchisees, the franchisees are not required to carry 
the worker's compensation and other liability insurance. However, CNT franchisees would be limited in how, and to what extent, they supervised the nannies and tutors, in order to maintain their status as independent contractors. Too much supervision or control by CNT could jeopardize the independent contractor status. Too little makes it difficult to protect the CNT brand, as CNT has no assurance the service delivered by the nannies and tutors to the client families meets the quality standards of CNT.

\section{Staffing Model}

The staffing business model is used by many employment agencies that provide temporary employees to businesses who need short term workers or desire more flexible staffing. In this model, the CNT franchisee finds, screens, and places the nanny or tutor, and handles the payroll and taxes. In this model, the liability insurance is carried by the employer, not the staffing agency. The tension in this model is similar to the independent contractor model; the franchisee cannot exert much control over how the nanny or tutor does their job or they may be classified as employees of the franchisee, shifting the liability insurance back to the franchisee. In addition, the family is expected to assume the role of the employer for the nanny or tutor.

\section{Headhunter Model}

In a headhunter model, the family pays the CNT franchisee to find, screen, and place a nanny or tutor for a one-time fee. Keeley's initial idea is for franchisees to charge a placement fee of $\$ 500$ - $\$ 1000$, depending on the number of hours, skills desired by the family, etc., and Keeley receives a one-time royalty percentage on that placement fee from the franchisee. In some systems, franchisees say they like this model. Whenever they made a placement, they receive a fairly large check from the family, and since the nanny/tutor is an employee of the family, this model freed the CNT franchisee from being considered an employer. But if CNT received a royalty only on the initial placement fee, Keeley estimated his one-time royalty rate would have to be $20 \%$ or more of the placement fee to justify the cost of running his franchisee support infrastructure. He feared that such a high royalty rate would make it difficult to attract franchisees to the system and to keep them focused on providing good customer service to existing customers, which could jeopardize the CNT brand. In addition, the system would emphasize making placements in order to earn the one-time fee vs. managing the ongoing customer relationships with nanny and tutor client families, another potential threat to the CNT brand.

\section{Back at the Office}

As Keeley looked at the list of insurance companies he could call to seek the necessary insurance, he wondered if any insurance company would underwrite the coverage he needed for the traditional franchising model. Despite his belief the traditional franchise model was the right one for CNT, he wondered if he should consider a different franchisee business model so CNT franchisees could avoid the liability insurance problem and he could get on with growing the company before new competitors emerged. Should he reach for the phone or not?

\section{College Nannies and Tutors (B)}

Keeley continued to believe that traditional franchising was the right business model, but he didn't find the general and professional liability insurance and workers compensation coverage he needed until after contacting, directly and indirectly, 57 insurance providers. Most underwriters were simply not comfortable with the concept of covering primarily college-age students to provide unsupervised childcare. Even when Keeley found a company willing to provide the coverage, the lack of claim or rating experience for this type of work meant high premiums. In the beginning, the nannies working for CNT were rated at nearly $11 \%$ of wages for workers' compensation insurance, which was higher than the rate paid by many construction companies covering their workers. But over time, the CNT franchisees were able to get better rates as underwriters gained confidence in claim rates, and CNT eventually developed a competitive advantage through its national insurance program for both general and professional liability; its workers' compensation rate decreased to an average of $2 \%$.

Keeley always believed in providing excellent support to his franchisees, and one of the "value adds" CNT developed for franchisees was a technology platform to help franchisees run their units. Keeley evaluated a plethora of systems on the market, but nothing existed that included all the key elements required for running the day-to-day operations of a College Nannies \& Tutors franchise. So he designed what would become the CNeT system. CNeT is a complete front and back of 
house web-based platform that functions as a CRM, scheduling program, database, document and training manager, and web portal. $\mathrm{CNeT}$ is one of the key differentiators in the CNT franchise sales process for attracting the right franchisees. As one owner stated, ""The CNeT system offers tremendous tools to manage my business. It is portable and allows me, as an owner, the ability to maintain day to day contact with families, employees and related elements of the business no matter where I am. From 1000 miles away, I am still able to check in on employee applications, placements and hours logged. I am able to maintain contact with all my customers because I have a complete and accurate "file cabinet" within the CNeT system."

In 2005, CNT added on-call in-home care services for an ill child or day care problem as part of their franchise business. CNT provides a sitter for a child at home when ill or not in school/day care, enabling the parent to go to work, and the cost is often funded by the parent's employer. This business was a new revenue stream for CNT, contracting directly with employers where they had willing franchisees, and entering vendor agreements with other day care centers that wanted to offer the service to their clients.

One of those partners was Bright Horizons, the Bostonbased, $\$ 1.5$ billion revenue operator of day care centers and on-demand sitters. As a vendor for Bright Horizons, CNT was doing about $\$ 10$ million in business annually through Bright Horizons' 900 day-care centers that sell "family services" to many large companies as part of a fast-growing division called Care Advantage. If an employee can't get to work, because of an ill child or a day-care provider who is ill or on vacation, Bright Horizons will send an in-home care provider to the home who is actually a contracted CNT employee.

In 2016, Keeley sold CNT to Bright Horizons for an undisclosed sum. "I had to determine what's the right answer to accelerate the company and when a $\$ 1.5$ billion company approaches you listen" said Keeley, who stayed on to run CNT for Bright Horizons. "I'm not done yet," Keeley said. "I'm excited to stay on. This also is best for our franchisees."

\section{Reference}

"Mergers-and-acquisitions business slowed in 1st half of ' 16 ", by Neal St. Anthony and Patrick Kennedy, Minneapolis Star Tribune, July 25, 2016. (http://www.st artribune.com/mergers-and-acquisitions-business- slowed-in-the-first-half-of-2016/388000072/ Accessed June 22, 2017).

Additional Search Terms: entrepreneurship courses, teaching ideas, teaching resources, classroom ideas, entrepreneurship classes, business schools, business school classes, entrepreneurship students, professors 